\title{
PENGEMBANGAN ALAT UKUR KHUSYUK SHOLAT DALAM KAITAN PENGARUH POSITIFNYA BAGI KESEHATAN
}

\author{
Yusuf Alam Romadhon \\ Fakultas Kedokteran Universitas Muhammadiyah Surakarta \\ Korespondensi: dr. Yusuf Alam Romadhon, M. Kes. Email: yar245@ums.ac.id
}

\begin{abstract}
Abstrak
Khusyuk dalam sholat merupakan pengalaman personal yang belum banyak dikaji. Banyak penelitian eksperimental menunjukkan pengaruh positif sholat bagi kesehatan, tetapi penelitian skala luas mendapatkan hasil sebaliknya di Indonesia. Penelitian ini bertujuan mengembangkan instrumen pengukuran khusyuk sholat dalam kaitan pengaruh positifnya bagi kesehatan yang berbahasa Indonesia penelitian ini terdiri dari 3 fase. Fase I: eksplorasi literatur dan studi kualitatif untuk mendapatkan konsep kunci dan operasionalisasi konsep kunci. Fase II: pengembangan dan penajaman item berdasarkan operasionalisasi konsep kunci. Fase III: studi pendahuluan dan analisis statistik. Hasil eksplorasi literatur dan studi kualitatif didapatkan 4 domain konsep utama dan 11 sub domain tentang khusyuk; 1) status khusyuk terdiri dari a) induksi perubahan kesadaran karena niat, b) Isolasi mental perubahan kesadaran diri, c) peragaan dialog mental dengan Allah, d) faktor pemampu khusyuk, e) pengendalian mind wandering; 2) prasyarat keyakinan dan God attachment terdiri dari a) keyakinan kuat bertemu Allah dan b) God attachment; 3) atmosfer spiritual terdiri dari a) kesiapan hati, kelonggaran waktu dan suasana tempat dan b) kondisi psikologis tertentu dan kematangan spiritual; 4) dampak khusyuk terdiri dari a) restrukturisasi kognitif peristiwa kehidupan dan b) perasaan segar, tenang dan rileks. Pengembangan item selanjutnya direview oleh pakar agama dan psikiatri untuk mendapatkan validitas isi. Setelah mengkoreksi item-item dengan korelasi item - total rendah, didapatkan 42 item dengan Cronbach's Alpha .945.
\end{abstract}

Kata Kunci: Alat Ukur Khusyuk, Kesehatan

\begin{abstract}
Devotion in Islamic prayer is a personal experience that has not been widely studied. Many experimental studies have shown a positive effect on Islamic prayer for health, but large-scale research has the opposite results in Indonesia. The objective of this study are develop instruments for measuring solemn prayer in relation to its positive influence on health in Indonesian Three research phases were carried out. Phase I: literature exploration and qualitative studies to get key concepts and operationalize key concepts. Phase II: development and sharpening of items based on the operationalization of key concepts. Phase III: preliminary study and statistical analysis. The results of literature exploration and qualitative studies obtained 4 main concept domains and 11 sub domains about solemn; 1) solemn status consists of a) induction of change in consciousness due to intention, b) Isolation of mental changes in self-awareness, c) demonstration of mental dialogue with God, d) solemn enabling factors, e) mind wandering control; 2) the prerequisites for belief and the God attachment consists of a) strong belief in meeting God and b) God attachment; 3) the spiritual atmosphere consists of a) heart readiness, looseness of time and atmosphere of the place and b) certain psychological conditions and spiritual maturity; 4) solemn effects consist of a) cognitive restructuring of life events and b) feeling refreshed, calm and relaxed. The item development was then reviewed by religious and psychiatric experts to obtain content validity. After correcting items with a low total-item correlation, 42 items were obtained with Cronbach's Alpha .945.
\end{abstract}

Keywords: Solemn Measuring Instrument, Health 


\section{PENDAHULUAN}

\begin{abstract}
Khusyuk dalam sholat merupakan pengalaman subyektif khas sholat yang belum banyak dikaji secara mendalam dari literatur yang ada. Meskipun demikian, perilaku sholat secara umum telah banyak diteliti tentang kemanfaatannya bagi kesehatan. Dalam penelitian sebelumnya terdapat pertentangan antara hasil penelitian skala luas mengenai perilaku sholat dengan risiko hipertensi pada populasi wanita di
\end{abstract} Indonesia, dengan berbagai penelitian eksperimental mengenai pengaruh sholat dan dzikir terhadap perbaikan performa kardiovaskuler ${ }^{1,2,3}$. Perbedaan hasil yang berlawanan ini memunculkan spekulasi adanya variabel antara yang menjelaskan mengapa perilaku sholat bagi sebagian subyek mempunyai dampak positif bagi kesehatan, sementara bagi sebagian lainnya tidak. Dengan mengacu pada pembedaan spiritualitas dan religiusitas, dimana spiritual merupakan pengalaman pribadi, intim dan individual, sedangkan religiusitas merupakan bentuk formal, sosial dan dogma ${ }^{4}$, maka temuan berlawanan tersebut dapat diinterpretasikan bahwa subyek dalam penelitian eksperimental lebih kuat aspek spiritualitas dalam praktek sholat mereka, sedangkan pada subyek populasi luas, sholat lebih menonjol pada aspek formal agama atau religiusitasnya. Karena itu diperlukan studi yang mengeksplorasi konstruk-konstruk kunci aspek spiritualitas sholat yakni perilaku khusyuk sholat yang berpotensi sebagai faktor determinan bagi kesehatan pada umumnya serta mengkuantifikasinya. Data empiris menyebutkan bahwa baik spiritualitas maupun religiusitas merupakan sumberdaya kesehatan yang potensial. Terdapat tiga mekanisme utama yang menyebabkan berefek positif bagi kesehatan adalah: 1) gaya hidup sehat dan menghindari dari perilaku yang berisiko bagi kesehatan dikarenakan kecenderungan spiritualitas dan religiusitas, 2) dukungan dan keterikatan sosial yang kuat bagi mereka yang religious, 3) meningkatnya kesadaran koheren dan makna hidup sebagai dampak dari gagasan dan praktek spiritual. Pengalaman spiritual dan pengaruh intrapersonal difasilitasi oleh praktek spiritual, kontemplatif atau meditatif disamping seperangkat keyakinan, sikap dan perilaku mempunyai peran penting dalam memberikan efek baik bagi kesehatan ${ }^{5}$. 
Spiritualitas Islam telah banyak dikaji, tetapi bersifat umum dalam praktek beragama ${ }^{6,7,8}$. Khusyuk dalam sholat merupakan pengalaman personal khusus berkaitan ibadah formal sholat. Pengalaman personal subyektif fenomenologik aktivitas meditasi (yang identik dengan sholat) telah banyak dieksplorasi kualitatif dan kuantitatif ${ }^{9}, 10$. Pengukuran pengalaman khusyuk dalam sholat belum banyak dieksplorasi dan belum ada alat ukur secara kuantitatif dalam konteks orang Indonesia.

\section{METODE}

Penelitian ini dilakukan di Indonesia dan item-item dikembangkan dalam bahasa Indonesia. Penelitian ini dilakukan secara multistage meliputi tiga fase: 1) identifikasi domain khusyuk sholat, operasionalisasi konstruk khusyuk dari kajian literatur tentang neurosains tingkat kesadaran, salutogenik Antonovsky, pray as medicine, God attachment, dan pendekatan kognitif perilaku $11,12,13,14,15,16,17,18,19,20,21,22$ serta buku-buku teks Islam tentang tąkiyatunnafs, sholat khusyuk, dan kitab klasik Ibya ulumuddin 23,24,25,26,27,28,29,30, serta diperkuat dengan studi kualitatif pada narasumber kunci; kemudian dilanjutkan dengan pengembangan dan pengelompokan item-item, 2) evaluasi item pernyataan oleh ahli agama dan ahli kesehatan jiwa, 3) studi pendahuluan, pengumpulan data dan analisis statistik.

\section{HASIL DAN PEMBAHASAN}

Kerangka konseptual khusyuk dan dampak baiknya bagi kesehatan diuraikan dalam gambar 1. Khusyuk secara umum didefinisikan sebagai pengalaman personal kompleks khas sholat dimana pelaku sholat yang mempunyai keyakinan dasar bertemu dan menunjukkan adanya kelekatan dengan Allah dapat mencapai status kesadaran khusyuk melalui pengondisian atmosfer spiritual dan mempunyai dampak positif bagi kesehatan.

Status khusyuk merupakan diskripsi detil dari pengalaman fenomenologik dari khusyuk. Secara umum dikatakan bahwa khusyuk adalah perubahan kesadaran diri dari kesadaran basal menuju kesadaran khusyuk yang diinduksi oleh niat, pada kesadaran khusyuk ini pelaku sholat dapat menghadirkan Allah seolah-olah nyata, mengungkapkan penghambaan, pemujaan dan permohonan melalui bacaan dan gerakan sholat yang difahami dalam ruang isolasi mentalnya, dan 
adanya pengendalian mind wandering selama proses tersebut.

Selanjutnya dalam hal penghadiran Allah, pemahaman arti bacaan dan maksud gerakan sholat, serta kemampuan merasakan sholat sebagai ungkapan hati diuraikan secara skematik pada gambar 2.

Induksi perubahan kesadaran dengan niat, karena niat mempunyai tiga komponen yakni 1) iradat (keinginan kuat), 2) ibtigha (mencari dengan sunguh-sungguh) dan 3) bimmah (terobsesi dengan Allah dan sholat). Niat yang tidak adekuat tidak menghantarkan pada perubahan menuju kesadaran khusyuk. Kesadaran khusyuk pada tingkat autobiografik episodik pada gambar 2 digambarkan sebagai kuadran kiri atas dapat menyebabkan isolasi mental secara sempurna sehingga mind wandering tidak terjadi. Domain kedua keyakinan dasar akan bertemu Allah didasari dari Al-Qur'an Surat Al-Baqarah ayat 46 bahwa khusyuk ada keyakinan akan bertemu dengan Allah, menegaskan bahwa sholat merupakan praktik spiritual agama Islam. Khusyuk dalam sholat tidak akan tercapai apabila tidak ada keyakinan mendasar mengenai hal tersebut. Kelekatan pada Tuhan dalam konteks sholat mengandung empat pengertian: mempertahankan kedekatan kepada Allah, keyakinan bahwa Allah merupakan sumber keamanan, dan bersama Allah hati menjadi tenang, dan mengalami kegelisahan apabila tidak ada upaya mendekatkan diri padaNya.

Domain ketiga atmosfer spiritual merupakan upaya persiapan yang harus dilakukan untuk mencapai status khusyuk. Definisi atmosfer spiritual adalah upaya untuk menciptakan keadaan yang meningkatkan "tone" khusyuk menjelang pelaksanaan sholat. Terdapat dua sub domain yaitu aspek fisik dan mental, seperti kesiapan hati dan tempat serta kelonggaran waktu. Kedua pengondisian suasana spiritual baik dalam mengingat Allah maupun kontemplasi awal sebelum sholat.

Domain keempat dampak khusyuk yang terdiri dari dua subdomain yaitu restrukturisasi kognitif yang mengoreksi bias dalam mempersepsi peristiwa kehidupan (bias ini membuat seseorang berisiko mengalami gangguan mental) dan perbaikan perilaku, suasana hati dan kondisi fisik tubuh.

Pengembangan dan penajaman item pernyataan untuk masing-masing domain/sub

Vol. 6 No.1 Februari 2019 


\section{Konseptualisasi Khusyuk Operasionalisasi konsep khusyuk}

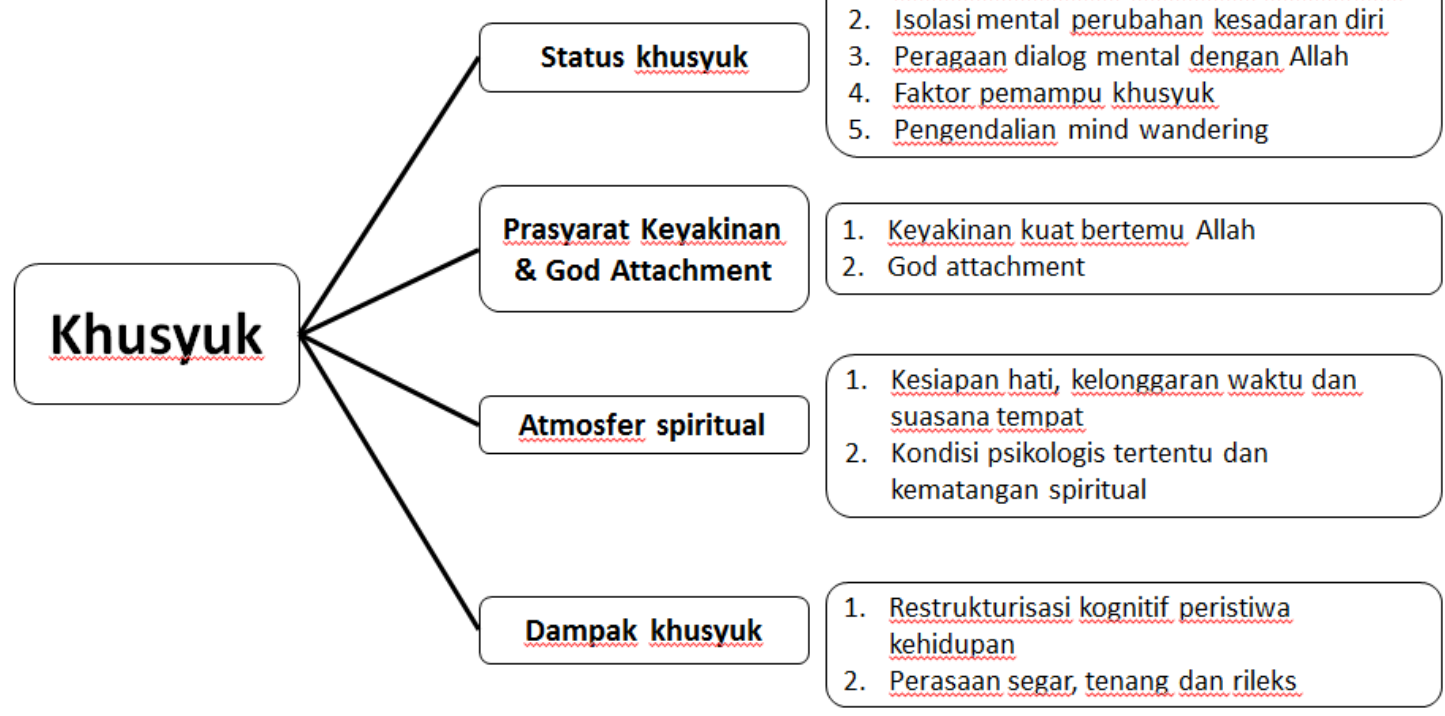

Gambar 1. Kerangka konseptual khusyuk dan dampak baiknya bagi kesehatan. Terdapat empat domain utama khusyuk dan 11 sub domain khusyuk.

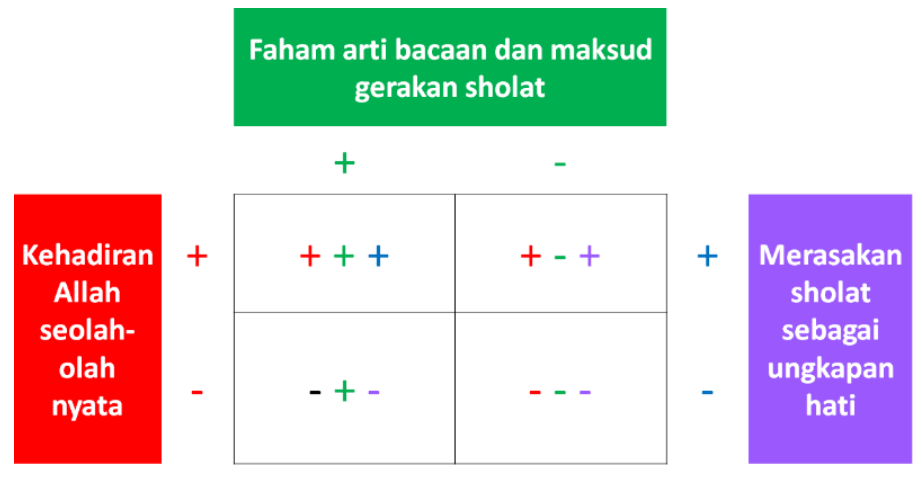

Gambar 2. Matriks yang menggambarkan bagaimana bauran khusyuk antara ketiga indikator subyektif yakni kehadiran Allah seolah nyata, pemahaman arti bacaan dan maksud gerakan sholat serta merasakan sholat sebagai ungkapan hati. Kuadran kiri atas: kesadaran autobiografik episodik sholat dengan pemahaman bacaan yang baik, kuadran kanan atas: kesadaran autobiografik episodik sholat tanpa pemahaman bacaan yang baik, kuadran kiri bawah: kesadaran semantik sholat, kuadran kanan bawah kesadaran prosedural.

domain konseptual yang telah Indonesia, masing-masing dua orang untuk dioperasionalisasikan direview oleh pakar agama mendapatkan validitas isi dan bahasa. Masingdan psikiatri yang sehari-harinya berbahasa masing pernyataan diberikan pilihan tujuh skala 
Likert dari sangat sesuai diberikan nilai 7 hingga sangat tidak sesuai diberikan nilai 1 untuk pernyataan yang favorable. Sedangkan pernyataan unfavorable skoring berkebalikan dengan yang favorable. Item pernyataan yang berhasil disusun, kemudian dilakukan uji coba pada 90 mahasiswa kedokteran. Setelah dilakukan koreksi untuk nilai korelasi item - total yang rendah akhirnya didapatkan 42 pernyataan dengan nilai alfa Cronbach 0.945.

Kusioner ini secara teoretis valid karena telah direview oleh pakar di bidangnya (psikiatri, psikolog, dan agama Islam) serta reliabel ketika digunakan sebagai instrumen pengukuran dalam penelitian pendahuluan. Alat ukur ini selanjutnya perlu diuji dengan indikator-indikator kesehatan mental subyektif lainnya, seperti tingkat stres, tingkat kecemasan, dan tingkat depresi, dimana secara teoretis berkorelasi terbalik. Indikator mental subyektif lainnya seperti kualitas hidup juga perlu diujikan, dan secara teoretis berkorelasi positif. Beberapa indikator biologis stres lainnya seperti heart rate variability (HRV) yang merupakan indikator biologis aktivitas syaraf simpatis atas parasimpatis pada ritme jantung, atau skin galvanometric indikator biologis stres pada kulit, dan beberapa indikator yang umumnya digunakan dalam pemeriksaan biofeedback. Validitas eksternal lain yang dapat diujikan dari alat ukur ini misalnya indikator-indikator stres kronik atau beban alostatik seperti hs-CRP (high sensitivity Creactive protein), gangguan metabolisme lemak, metabolisme glukosa, dan beberapa indikator inflamasi sistemik lainnya seperti interferon gamma, ICAM-1 (intercellular adhesion molecule - 1), TGF- $\beta$ (transforming growth factor - $\beta$ ) yang lebih lanjut dapat digunakan sebagai indikator kesehatan kardiovaskuler 31,32,33,34,35,36,37,38. Pengujian-pengujian ini untuk memperhitungkan peran khusyuk sebagai variable antara terhadap indikator-indikator risiko biomolekuler kesehatan.

\section{SIMPULAN}

Alat ukur kekhusyukan dalam kaitan pengaruh positifnya bagi kesehatan ini, memiliki validitas teori dan bahasa serta reliabel dalam penelitian pendahuluan. Selanjutnya perlu uji validitas eksternal dengan mengorelasikan dengan indikator-indikator kesehatan mental subyektif lainnya dan indikator-indikator biologis stres dan kesehatan. 


\section{DAFTAR PUSTAKA}

1. Jansen, N., 2017, Between- and WithinReligion Differences in Hypertension Risks for Indonesian Women, Population Association of America 2017 Annual Meeting Final Program, April 27 - 29

2. Senik, M.R., Abdul-Wahab, M.N., and Zamani, M. 2013. The Study Of heart rate variability (hrv) Biofeedback Through Zikir (Islamic Recitation) of High School Students, Proceed Malay Tech Univ Conf Engin \& Tech 3-4 Dec

3. Sholeh, M. 2000. Pengaruh Sholat Tahajjud terhadap Peningkatan Perubahan Respon Ketahanan Tubuh Imunologik, Disertasi: Universitas Airlangga Surabaya

4. Streib, H., and Hood, R.W. 2011. "Spirituality" as Privatized ExperienceOriented Religion:Empirical and Conceptual Perspectives, Implicit Religion (online) doi:10.1558/imre.v14i4.433

5. Kohls, N., Sauer, S., Offenbacher, M., and Giordano, J. 2011. Spirituality: an overlooked predictor of placebo effects? Phil. Trans. R. Soc. B. 366;1838-1848 doi:10.1098/rstb.2010.0389

6. Dasti, R. 2014. Development of a Multidimensional Measure of Islamic Spirituality (MMS), Journal of Muslim Mental Health Vol 8, Issue 2, 2014 http://dx.doi.org/10.3998/jmmh.103816 07.0008 .204

7. Bonab, B.G., Miner, M., and Proctor, M.T. 2013. Attachment to God in Islamic Spirituality, Journal of Muslim Mental Health Vol 7, Issue 2, 2013 http://hdl.handle.net/2027/spo.1038160 7.0007.205

8. Raiya, H.A. 2008. A Psychological Measure of Islamic Religiousness: Evidence for Relevance, Reliability and
Validity, A Dissertation Submitted to the Graduate College of Bowling Green State University

9. Leigh, J., Bowen, S., and Marlatt, G.A. 2005. Spirituality, mindfulness and substance abuse, Addict Behav 30 13351341

10. Ospina, M.B., Bond, K., Karkhaneh, M., Tjosvold, L., Vandermeer, B., Liang, Y., Bialy, L., Hooton, N., Buscemi, N., Dryden, D.M., Klassen, T.P. 2007. Meditation Practices for Health: State of the Research, AHRQ Publ No. 07-E010 June

11. Cahn, B.R., and Polich, J. 2006. Meditation States and Traits: EEG, ERP, and Neuroimaging Studies, Psychological Bulletin, Vol.132, No.2, 180-211

12. Chen, A.C.N., Feng, W., Zhao, H., Yin, Y., Wang, P., 2008, EEG default mode network in the human brain: Spectral regional field powers, Neuroimage. 41: $561-574$

13. Ardila, A., 2016, Is "Self-Consciousness" Equivalent to "Executive Function"? Psychology \& Neuroscience (2016, May 23) http:/ / dx.doi.org/ 10.1037/pne0000052

14. Berkovich-Ohana, A., and Glicksohn, J. 2014. The consciousness state space (CSS) - a unifying model for consciousness and self, Frontiers in Psychology April vol 5 article 341 doi: 10.3389/fpsyg.2014.00341

15. Martinelli, P., Sperduti, M., and Piolino, P., 2012, Neural Substrates of the Self Memory System: New Insights from a Meta - Analysis, Hum Brain Mapp 00.000000, 2012 DOI: 10.1002/ bbm.22008

16. McAdams, D.P., 2013, The Psychological Self as Actor, Agent, and Author, Perspectives on Psychological Science 8(3) 272 295 DOI: $10.1177 / 1745691612464657$

Vol. 6 No.1 Februari 2019 
17. Tulving, E., 1995, Organization of Memory: Quo Vadis? In Michael S. Gazzaniga (ed.), The Cognitive Neurosciences. MIT Press. pp. 839—847

18. Antonovsky, A. 1991. The Salutogenic Approach to Family System Health:Promise and Danger, European Congress on "Mental Health in European Families", Prague, Czechoslovakia, 5-8 May

19. Beck, A.T. 2008. The Evolution of the Cognitive Model of Depression and Its Neurobiological Correlates, Am J Psychiatry; 165:969 977

20. Granqvist, P. 2002. Attachment and Religion, an Integrative Developmental Framework, 2010, Dissertation for the Degree of Doctor of Phylosophy in Psychology presented at Uppsala University

21. Granqvist, P., Mikulincer, M., and Shaver, P.R. 2010. Religion as Attachment: Normative Processes and Individual Differences, Personality and Social Psychology Review 14(1) 49 -59

22. Jankowski, P.J., and Sandage, S.J. 2014, Attachment to God and Humility: Indirect Effect and Conditional Effects Models, Journal of Psychology \& Theology2014, Vol. 42, No. 1, 70-82

23. Al-Jauziyah, I.Q. 2011. Al-Jawaabul Kaafii Liman Sa'ala 'anid Dawaa' Asy-Syaafi, Pen Darul Aqidah, Iskandariah Mesir, Ed Indonesia, Al-Jawaabul Kaafii Solusi Qur'an dalam Mengatasi Masalah Hati, Pen Al-Qowam.

24. Al-Jauziyah, I.Q. 2015, Madarijus Salikin, Penerbit Pustaka Al-Kautsar, 2015

25. Al-Qahthani. 2013. Al-kbusyu' fish Shalah fi Dhau'il Kitab was Sunnah, ed Indonesia Panduan Lengkap Sholat Khusyuk, Pen Zam-zam Solo

26. Ghazali, I. 2014. Mukbtashar Ibya' Ulumuddin Edisi Indonesia Ringkasan Ihya'
Ulumuddin Cetakan keduapuluh, Penerbit Sahara, Bekasi, Indonesia

27. Hawwa, S., 2014. Al-Mustakblash fi Tazkiyatii Anfus, edisi Indonesia, Tazkiyatun Nafs, Penerbit Era Adicitra Intermedia.

28. Ibnu-Rajab, 2012, Jamiul Ulum wal Hikam fi Syarbi Hadits Sayyidil Arab wal Ajm Edisi Indonesia Panduan Ilmu dan Hikmah Jamiul Ulum wal Hikam cetakan keempat 2012 Penerbit PT Darul Falah Bekasi Indonesia

29. Khalid, A., 2003. Ibadatul Mu'min, Penerbit Darul Ma'rifah, 1423 H/2003, Edisi Indonesia, Ibadah sepenuh hati, Penerbit Aqwam.

30. Khalid, A., 2011. Khowatir Qur'aniyah, Nazharat fi abdafi suwarii Qur'an, Ad-Darul Arabiyah Lil 'Uluum, 1425 / 2004, Edisi Indonesia, Khowatir Qur'aniyah: Kunci memahami tujuan surat-surat Al-Qur'an, Penerbit Al-I'tishom

31. Wilson, P.W.F., Pencina, M., Jacques, P., Selhub, J., D'Agostino, R., O'Donnell, J. 2008. C-Reactive Protein and Reclassification of Cardiovascular Risk in the Framingham Heart Study, Circ Cardiovasc Qual Outc;1:92-97.

32. Lawson, C., and Wolf, S. 2009. ICAM-1 signaling in endothelial cells, PharmReports, $61,22-32$

33. Chen, C., Lei, W., Chen, W., Zhong, J., Gao, X., Li, B., Wang, H., Huang, C. 2014. Serum TGF- $\beta 1$ and SMAD3 levels are closely associated with coronary artery disease, BMC Cardiovascular Disorders 4, $14: 18$

34. Taleb, S. 2016. Inflammation in atherosclerosis, Arch Cardiovasc Dis 109, $708-715]$

35. Dhaouadi, N., Li, J-Y., Feugier, P., Gustin, M-P., Dab, H., Kacem, K., Bricca, G., Cerutti, C. 2014.

Vol. 6 No.1 Februari 2019 
Computational identification of potential transcriptional regulators of TGF-B1 in human atherosclerotic arteries, Genomics103; 357-370

36. Ramji, D.P., and Davies, T.S. 2015. Cytokines in atherosclerosis: Key players in all stages of disease and promising therapeutic targets, Cyt \& Growth Factor Rev $26673-685$
37. Ridker, P.M., Hennekens, C.H., Buring, J.E., and Rifai, N. 2000. C-reactive protein and Other Markers of Inflammation in the Prediction of Cardiovascular Disease in Women, N Engl J Med;342:836-43.

38. Pfützner, A., and Forst, T. 2006. HighSensitivity C-Reactive Protein as Cardiovascular Risk Marker in Patients with Diabetes Mellitus, Diab Tech \& Ther Vol 8, No 1

Tabel 1. Item - Total Correlation Kuesioner

\begin{tabular}{|c|c|c|c|c|c|}
\hline Domain & Sub domain & & Pernyataan & $\begin{array}{l}\text { Fav } \\
\text { fav }\end{array}$ & $\begin{array}{l}\text { Item - } \\
\text { total } \\
\text { corr }\end{array}$ \\
\hline \multirow[t]{16}{*}{$\begin{array}{l}\text { Status } \\
\text { khusyuk }\end{array}$} & \multirow{3}{*}{$\begin{array}{l}\text { 1. Induksi } \\
\text { perubahan } \\
\text { kesadaran } \\
\text { dengan niat }\end{array}$} & P1 & $\begin{array}{l}\text { Saat akan memulai sholat, secara mental saya berusaha memunculkan } \\
\text { keinginan kuat (iradat) saya untuk bermunajat kepada Allah }\end{array}$ & $\sqrt{ }$ & .525 \\
\hline & & $\mathrm{P} 2$ & $\begin{array}{l}\text { Sebelum memulai sholat, secara mental saya berusaha bersungguh- } \\
\text { sungguh (ibtigha) agar hati saya dapat terhubung dengan Allah }\end{array}$ & $\sqrt{ }$ & .525 \\
\hline & & $\overline{\mathrm{P} 3}$ & $\begin{array}{l}\text { Ketika akan memulai sholat, secara mental saya sudah menjadikan } \\
\text { Allah sebagai perhatian utama (bimmah) }\end{array}$ & $\sqrt{ }$ & 619 \\
\hline & \multirow{5}{*}{$\begin{array}{l}\text { 2. Perubahan } \\
\text { kesadaran } \\
\text { diri }\end{array}$} & P4 & $\begin{array}{l}\text { Saat melakukan sholat, saya benar-benar memahami makna dan } \\
\text { maksud dari bacaan sholat yang saya ucapkan }\end{array}$ & $\sqrt{ }$ & 682 \\
\hline & & $\overline{\mathrm{P} 5}$ & $\begin{array}{l}\text { Pada saat melakukan sholat, saya benar-benar menghayati makna dan } \\
\text { maksud dari setiap gerakan sholat yang saya lakukan }\end{array}$ & $\sqrt{ }$ & .729 \\
\hline & & $\overline{\mathrm{P} 6}$ & $\begin{array}{l}\text { Pada saat melakukan sholat, saya melakukan penggambaran secara } \\
\text { nyata dari setiap bacaan sholat yang saya lantunkan (seperti saat } \\
\text { membaca "Maalikiyaumiddiin" terbersit dalam benak saya dahsyatnya } \\
\text { hari pembalasan) }\end{array}$ & $\sqrt{ }$ & 623 \\
\hline & & $\overline{\mathrm{P} 7}$ & Saya membaca bacaan shalat dengan tenang & $\sqrt{ }$ & .625 \\
\hline & & P8 & Saya menikmati setiap gerakan shalat yang saya lakukan & $\sqrt{ }$ & .658 \\
\hline & \multirow{4}{*}{$\begin{array}{l}\text { 3. Memeraga- } \\
\text { kan dialog } \\
\text { mental } \\
\text { dengan } \\
\text { Allah }\end{array}$} & P9 & Saya merasakan kehadiran dan kedekatan Allah ketika saya sholat & $\sqrt{ }$ & .742 \\
\hline & & $\overline{\mathrm{P} 10}$ & Saya merasakan rintihan dan doa saya didengar Allah pada saat sholat & $\sqrt{ }$ & .706 \\
\hline & & P11 & $\begin{array}{l}\text { Saya merasakan kondisi paling dekat dengan Allah pada saat saya } \\
\text { sujud }\end{array}$ & $\sqrt{ }$ & .498 \\
\hline & & $\overline{\mathrm{P} 12}$ & $\begin{array}{l}\text { Saya merasakan bahwa Allah memperhatikan setiap gerak fisik dan } \\
\text { batin saya selama sholat }\end{array}$ & $\sqrt{ }$ & .632 \\
\hline & \multirow{3}{*}{$\begin{array}{l}\text { 4. Jenis } \\
\text { khusyuk } \\
\text { dan faktor } \\
\text { pemampu } \\
\text { ke- } \\
\text { khusyukan }\end{array}$} & P13 & $\begin{array}{l}\text { Bila saya dapat melakukan sholat dengan khusyuk, perhatian saya } \\
\text { secara berimbang tertuju baik pada Allah maupun penghayatan akan } \\
\text { makna bacaan dan gerakan sholat }\end{array}$ & $\sqrt{ }$ & .424 \\
\hline & & $\overline{\mathrm{P} 14}$ & $\begin{array}{l}\text { Kekhusyukan saya dalam sholat, lebih sering dipicu oleh penghayatan } \\
\text { akan makna bacaan sholat }\end{array}$ & $\sqrt{ }$ & .549 \\
\hline & & $\overline{\mathrm{P} 15}$ & $\begin{array}{l}\text { Kekhusyukan saya dalam sholat, lebih sering dipicu oleh penghayatan } \\
\text { akan gerakan sholat terutama saat sujud }\end{array}$ & $\sqrt{ }$ & .481 \\
\hline & \multicolumn{2}{|c|}{ 5. Pengendali-P16 } & Saya sepenuhnya dapat memfokuskan perhatian saya pada bacaan & $\sqrt{ }$ & .414 \\
\hline
\end{tabular}




\begin{tabular}{|c|c|c|c|c|c|c|}
\hline & \multirow{4}{*}{\multicolumn{2}{|c|}{$\begin{array}{l}\text { an mind } \\
\text { wandering }\end{array}$}} & & \multicolumn{3}{|l|}{ dan gerakan shalat } \\
\hline & & & P17 & $\begin{array}{l}\text { Konsentrasi saya sering terganggu oleh suara atau gambar atau bau } \\
\text { atau suasana di sekeliling saya ketika saya melakukan shalat }\end{array}$ & $\sqrt{ }$ & .337 \\
\hline & & & $\overline{\text { P18 }}$ & $\begin{array}{l}\text { Saya dapat mencermati setiap makna kalimat dari bacaan shalat yang } \\
\text { saya baca }\end{array}$ & $\sqrt{ }$ & .622 \\
\hline & & & $\overline{\mathrm{P} 19}$ & $\begin{array}{l}\text { Saya mengalami kesulitan dalam mencermati setiap makna kalimat } \\
\text { dari bacaan sholat yang saya baca }\end{array}$ & $\sqrt{ }$ & .556 \\
\hline \multirow{7}{*}{$\begin{array}{l}\text { Prasyarat } \\
\text { dasar dan } \\
\text { God } \\
\text { attachment }\end{array}$} & \multirow{3}{*}{ 6. $\begin{array}{l}\mathrm{K} \\
\mathrm{k} \\
\mathrm{b} \\
\mathrm{A}\end{array}$} & \multirow{3}{*}{$\begin{array}{l}\text { Keyakinan } \\
\text { kuat akan } \\
\text { bertemu } \\
\text { Allah }\end{array}$} & P20 & $\begin{array}{l}\text { Saya meyakini bahwa Allah merupakan penyebab segala sebab } \\
\text { kejadian yang ada di alam semesta, termasuk peristiwa hidup yang } \\
\text { saat ini saya hadapi dan kepadaNya kita akan kembali }\end{array}$ & $\sqrt{ }$ & .404 \\
\hline & & & $\overline{\mathrm{P} 21}$ & $\begin{array}{l}\text { Saya meyakini bahwa apa yang telah ditakdirkan Allah kepada saya } \\
\text { adalah yang terbaik bagi kehidupan saya baik di dunia maupun } \\
\text { akhirat }\end{array}$ & $\sqrt{ }$ & .403 \\
\hline & & & P22 & $\begin{array}{l}\text { Pada saat shalat, saya merasakan ketakutan tentang dahsyatnya hari } \\
\text { akhir, karena itu saya memohon dengan sangat perlindungan dan } \\
\text { bimbinganNya dalam menjalani kehidupan }\end{array}$ & $\sqrt{ }$ & .481 \\
\hline & & \multirow[t]{4}{*}{$\begin{array}{l}\text { God } \\
\text { attachment }\end{array}$} & P23 & $\begin{array}{l}\text { Saya yakin apabila saya dekat dengan Allah, Allah akan memberikan } \\
\text { kehidupan yang terbaik bagi saya dan keluarga saya di dunia dan } \\
\text { akhirat }\end{array}$ & $\sqrt{ }$ & .392 \\
\hline & & & $\mathrm{P} 24$ & Allah tampak tidak memedulikan urusan saya & $\sqrt{ }$ & .591 \\
\hline & & & P25 & Allah kadang tanggap terhadap kebutuhan saya, terkadang tidak & $\sqrt{ }$ & .500 \\
\hline & & & P26 & Saya merasakan bahwa Allah demikian penyayang kepada saya & $\sqrt{ }$ & .470 \\
\hline \multirow{8}{*}{$\begin{array}{l}\text { Penciptaan } \\
\text { atmosfer } \\
\text { spiritual }\end{array}$} & \multirow{4}{*}{$\begin{array}{ll}8 . & 1 \\
1 \\
1 \\
1 \\
1 \\
t\end{array}$} & \multirow{4}{*}{$\begin{array}{l}\text { kesiapan } \\
\text { hati, } \\
\text { kelonggara } \\
\text { n waktu } \\
\text { dan suasana } \\
\text { tempat }\end{array}$} & P27 & $\begin{array}{l}\text { Saya menyediakan waktu yang memadai dalam mempersiapkan diri } \\
\text { sebelum melakukan sholat }\end{array}$ & $\sqrt{ }$ & .446 \\
\hline & & & P28 & $\begin{array}{l}\text { Saya menyiapkan pakaian yang bersih dan harum sebelum } \\
\text { mengerjakan sholat }\end{array}$ & $\sqrt{ }$ & .466 \\
\hline & & & $\overline{\mathrm{P} 29}$ & $\begin{array}{l}\text { Saya menyiapkan tempat senyaman mungkin sebelum saya } \\
\text { melakukan sholat }\end{array}$ & $\sqrt{ }$ & .583 \\
\hline & & & $\overline{\mathrm{P} 30}$ & $\begin{array}{l}\text { Saya tidak menyediakan waktu secara khusus untuk persiapan diri } \\
\text { sebelum melakukan sholat }\end{array}$ & $\sqrt{ }$ & .478 \\
\hline & \multirow{4}{*}{$\begin{array}{ll}1 \\
1 \\
1 \\
1\end{array}$} & \multirow{4}{*}{$\begin{array}{l}\text { kondisi } \\
\text { psikologis } \\
\text { tertentu } \\
\text { dan } \\
\text { kematanga } \\
\text { n spiritual }\end{array}$} & P31 & Saya merasakan panggilan adzan itu sebagai panggilan dari Allah & $\sqrt{ }$ & .676 \\
\hline & & & P32 & $\begin{array}{l}\text { Saya mengondisikan diri saya dengan mengingat-ingat besarnya dosa } \\
\text { dan kelalaian saya dalam beribadah dan kehidupan sehari-hari saya } \\
\text { sebelum sholat, agar saya melakukan sholat dengan sungguh-sungguh } \\
\text { untuk mengampuni dosa dan menutupi kekurangan tersebut }\end{array}$ & $\sqrt{ }$ & .605 \\
\hline & & & $\overline{\mathrm{P} 33}$ & $\begin{array}{l}\text { Saya mengondisikan diri saya dengan mengingat-ingat karunia Allah } \\
\text { yang tidak ada taranya, sehingga saya dapat bersungguh-sungguh } \\
\text { untuk mengungkapkan rasa syukur saya ketika sholat }\end{array}$ & $\sqrt{ }$ & .724 \\
\hline & & & P34 & $\begin{array}{l}\text { Saya mengondisikan diri saya sebelum sholat dengan mengingat-ingat } \\
\text { terbatasnya umur saya dan ketidaktahuan kapan Allah memanggil } \\
\text { saya untuk kembali, sehingga saya merasakan sholat yang saya } \\
\text { lakukan adalah sholat yang terakhir dalam hidup saya }\end{array}$ & $\sqrt{ }$ & .351 \\
\hline \multirow{3}{*}{$\begin{array}{l}\text { Dampak } \\
\text { kognitif dar } \\
\text { afektif }\end{array}$} & \multirow{3}{*}{\multicolumn{2}{|c|}{$\begin{array}{l}\text { 10. Restrukturi } \\
\text {-sasi } \\
\text { kognitif } \\
\text { peristiwa } \\
\text { kehidupan }\end{array}$}} & P35 & $\begin{array}{l}\text { Tidak ada bedanya antara sebelum shalat dan sesudah shalat ketika } \\
\text { saya menghadapi permasalahan yang rumit }\end{array}$ & $\sqrt{ }$ & .586 \\
\hline & & & P36 & $\begin{array}{l}\text { Shalat membuat saya dapat melihat permasalahan hidup yang saya } \\
\text { hadapi menjadi lebih sederhana dibandingkan sebelum shalat }\end{array}$ & $\sqrt{ }$ & .652 \\
\hline & & & P37 & $\begin{array}{l}\text { Shalat membuat saya lebih mampu untuk memahami makna di balik } \\
\text { permasalahan hidup yang saya hadapi dibandingkan sebelum shalat }\end{array}$ & $\sqrt{ }$ & .631 \\
\hline
\end{tabular}




\begin{tabular}{|c|c|c|c|c|c|}
\hline & P38 & $\begin{array}{l}\text { Sholat tidak dapat mengantarkan saya melihat permasalahan hidup } \\
\text { yang saya hadapi menjadi lebih ringan bebannya }\end{array}$ & & $\sqrt{ }$ & .464 \\
\hline \multirow{4}{*}{$\begin{array}{l}\text { 11.Perasaan } \\
\text { segar, } \\
\text { tenang dan } \\
\text { rileks }\end{array}$} & P39 & $\begin{array}{l}\text { Shalat dapat membuat suasana hati saya menjadi lebih didominasi } \\
\text { emosi positif dibandingkan sebelum shalat }\end{array}$ & $\sqrt{ }$ & & .500 \\
\hline & P40 & Saya merasakan kesegaran fisik dan mental setelah melakukan sholat & $\sqrt{ }$ & & .409 \\
\hline & $\overline{\mathrm{P}} 41$ & $\begin{array}{l}\text { Saya merasakan perasaan lega secara emosional setelah melakukan } \\
\text { sholat }\end{array}$ & $\sqrt{ }$ & & .535 \\
\hline & $\overline{\mathrm{P} 42}$ & $\begin{array}{l}\text { Saya tidak merasakan perasaan lega secara emosional setelah } \\
\text { melakukan sholat }\end{array}$ & & $\sqrt{ }$ & .515 \\
\hline
\end{tabular}

Singkatan: fav: favorable; unfav: unfavorable 